\title{
Continuous Change in Curriculum: South Africanteachers' Perceptions
}

Prof Emmanuel O.Adu Ph.D.

\author{
Faculty of Education, University of Fort Hare, East London, South Africa \\ eadu@ufh.ac.za \\ Ms Nondwe C. P. Ngibe \\ Faculty of Education, University of Fort Hare, East London, South Africa \\ nondwengibe@gmail.com
}

Doi:10.5901/mjss.2014.v5n23p983

\begin{abstract}
South Africa experienced continuous change in education curriculum. This affected teachers in a way because teachers were not sure on how to implement the new curriculum introduced. They, (teachers), were confused and stressed and then that led to underperformance of learners in some schools. Therefore this study tends to explore and compile literatures on the perceptions of teachers about curriculum changes in South Africa. The study does not leave behind some literatures on concepts of education; curriculum in South Africa; an overview of curriculum policy in South Africa; curriculum changes to mention a few. The study however recommended among others that the South Africa Government should actively involve the teachers in formulating or drafting any policy that will affect curriculum since they are the custodians and implementers of the curriculum. Not only those changes in curriculum should not come overnight; there should a year or two for piloting any new curriculum so as to see the effect and its validity before being released for use in schools.
\end{abstract}

Keywords: Teacher, Curriculum, South Africa, Perceptions, Government.

\section{Introduction}

A curriculum is the offering of socially valued knowledge, skills and attitudes made available to students through a variety of arrangements during the time they are at school. Effective teaching can be defined as teaching which successfully achieves the learning by pupils intended by the teacher. The teacher must have a clear idea of what learning is to be fostered. He/she sets up and provides a learning experience which achieves this (Kyriacou, 2001).

The need for a complete overhaul of the education system under apartheid had been identified as a priority for building a new democratic South Africa (Valero \& Skovsmose, 2002). Apartheid was officially institutionalized in South Africa for several decades. This caused a number of inequalities amongst the non-White or Black (Black, coloured and Asian) and the White population groups, including access to better education.

Educational change has been stimulated by the major political changes which occurred in the country during the 1990s and which brought about the abolition of apartheid and the introduction of a democratic South Africa. The vision for education that emerged was to integrate education and training into a system of lifelong learning. South Africa is embarking on radical education reform (Valero \& Skovsmose, 2002). This is justified by continuous change in curriculum policy systems since 1997, when the first one was introduced in South Africa.

Curriculum 2005 (C2005) was introduced in 1997, Revised National Curriculum Statement (RNCS) in 2002, National Curriculum Statement (NCS) in 2007 and currently Curriculum and Assessment Policy Statements (CAPS) which was introduced in 2012. This means that Education policy is revisited time and again.

Outcomes Based Education (OBE) was therefore adopted as the approach that would enable articulation between education and training, recognition of prior learning and thus increase mobility for learners. The introduction of OBE was not only an attempt to change the education system but also for the purpose transforming society in the sense that parents and/ or learners' guardians has to own their children's education having a say and contribution as much as possible. Also, it was to transform education, particularly school education into something really worth wile to all citizens especially learners at schools.

New education policies formulated after 1994 sought to address the shortcomings in South Africa's previous education and training system. The above mentioned policy statements, namely, C2005, RNCS, NCS and CAPS, within a 
period of fifteen (15) years had been tried and followed in South Africa consecutively. The contents of the new curriculum imply that the learning experience in which the students are involved should be enjoyable, interesting and important so that the students should see the relevance of democracy in teaching and learning (Eastern Cape Education, 2003).

According to Mda and Mothatha (2000), formal and legal segregation of schools according to race and ethnic groups started in 1948 when the National Party (NP) came into power. They further stated that the racial and geographical divisions in the educational system led to the establishment of 15 Departments of Education before 1994. This means that there were different systems of education practised within one country.

After 1994 democratic elections, a new system of education was prepared by the African National Congress (ANC) led government. Mda and Mothatha (2000) say, "important directives emphasized in the document include: Integrated approach to education and training, Outcomes Based Education, Lifelong learning, access to education, training for all, equity, redress and transforming the legacies of the past."

Therefore, it is believed that the transformation of education in South Africa came with a lot of challenges to the government schools.

Yet if we look at the process, content, and achievements of public education, can any of us be confident that we are preparing young people well for the future in which they live? Are we contributing to the capabilities of a $21^{\text {st }}$ century society to govern itself wisely, to prosper economically and culturally, and to generate insight into pressing problems and build consensus change? (Costa \& Liebman, 1997)

Continuous change in curriculum affects the lives, relationships and working patterns of teachers, and the educational experiences of the learners. It affects parents by altering the education which their children receive, and thereby confirming or challenging their own expectations of what schools should be like.

It affects the community which is aware of the school through the outward conduct and attitude of pupils, rightly or wrongly understood. It affects employers, who derive their view of the curriculum from a rough and ready measurement of how the abilities and aptitudes of the boys and girls they recruit match their requirements.

A school curriculum is all about the fundamental reasons why children should learn what; It is all about the planning of learning content and subjects, and the philosophical (and pragmatic) reflection on all these matters (Van der Westhuysen, 1995) as cited in Steyn et al. 2006. Carl, 1994 in the same book concurs by saying that, but whatever the outcome of a curriculum design may be, a school curriculum can be regarded as successful only if it involves the teacher in as many curriculum decisions as possible.

In Steyn, Klerk and Du Plessies, 2006, it is said that although teachers are represented via teachers' unions. The freedom of the individual teacher to take the responsibility of his or her own professional duties is not protected. In a democratic, curriculum design includes the planning done by the departmental working groups; the design of an acceptable model; the design of criteria; the design of a draft curriculum and the launching and implementation of the final curriculum. But the question remains: what is the professional role and responsibility of the individual teacher?

\subsection{Rationale for the study}

South Africa experienced continuous change in education curriculum. This affected teachers in a way because teachers were not sure on how to implement the new curriculum introduced. They, (teachers), were confused and stressed and then that led to underperformance of learners in some schools.

In research made on teachers' current experiences regarding implementation of national curriculum statement, one teacher mentioned that continuous change in curriculum contributes in poor implementation of the curriculum (Ngibe, 2013).

The researchers feel that the continuous change affects the effective teaching and learning. The changes in curriculum make the teachers to struggle to reach the expected learner performance for some time until they master it. Within that period, existing curriculum is modified by the department of education.

They are required to shift from what they have practised and achieved and focus on the new policy statement brought to them. Teachers are not involved in any planning of the new curriculum and also in being the part in decision making, but they are the ones who are hands on in implementation. It is the feeling of the researchers to search literatures in order to know the perceptions of teachers about this. 


\section{Literature Review}

\subsection{Conceptualisation of Education: South African Perspectives}

Education, which is seen as the backbone of society, affects people. The Department of Education, (2003) believes that, the values, customs and culture of any society are therefore vital in formulating education policies, and so, the transition, as a process of change, must take into account societal interest.

South Africa is embarking on radical educational reform. The need for a complete overhaul of the education system under apartheid had been identified as a priority for building a new democratic South Africa (Valero \& Skovsmose, 2002). After 1994 democratic elections, a new system of education was proposed by the African National Congress (ANC) led government. Mda and Mothatha (2000:6) say, "important directives emphasised in the document include: Intergraded approach to education and training, Outcomes Based Education, Lifelong learning, access to education, training for all, equity, redress and transforming the legacies of the past.

Yes if we look at the process, content, and achievement at public education, can any of us be confident that we are preparing young people well for the future in which they live? Are we contributing to the capabilities of a $21^{\text {st }}$ century society to govern itself wisely, to prosper economically and culturally, and to generate insight into pressing problems and build consensus change? (Costa \& Liebman, 1997).

The aim of education is to develop young people to be better citizens (Department of Education, 2003). Citizenship is one of the many aspects of education. Fullan (1998), state that, the purpose of education is to prepare young people for life in society. Costa and Liebman, (1997), add by saying that, the intent of education is to aid the student in realizing that he/she is a thinking person equipped with a personal knowledge bank and a decision making instrument called mind.

\subsection{Curriculum in South Africa}

The word curriculum means the composite of content (e.g. science literacy) provided to learners as required by an authorised body responsible for schools and schooling usually under state law (Hewitt, 2006).

In this study, curriculum is understood to mean all subjects and activities which education authorities regard as necessary for the child to reach a certain level in his/her development, (Fourie, Grissel \& Verster, 1990).

Depending on how broadly educators define or employ the term, curriculum typically refers to the knowledge and skills students are expected to learn, which includes the learning standards or learning objectives they are expected to meet, the units and lessons that teachers teach, the assignments and projects given to students; the books; materials, videos, presentations and readings used in a course, and the tests, assessments, and other methods used to evaluate student learning (edglossary.org).

A school curriculum is all about the fundamental reasons why children should learn what; It is all about the planning of learning content and subjects, and the philosophical (and pragmatic) reflection on all three matters (Steyn, 2006)

Outcome-Based Education (OBE) can be understood as a concept or philosophy that frames the national curriculum in South Africa. The National curriculum is a primary source of support and direction for learning and teaching in the education system and plays the role of an equalizer in terms of educational standards (Eastern Cape Department of Education, 2003). The purpose of Outcomes Based Education in South Africa is to transform education, particularly school education, into something really worthwhile for all citizens (Jacobs, Vakalisa \& Gawe, 2006).

The successful implementation of an OBE curriculum requires teachers to be competent in applying a participative approach with practical understanding in their classes. Teachers (acting in loco parentis with regard to discipline and care) are trusted with the oversight and general direction of the child's education and the curriculum (Becher \& Maclure, 1998). But whatever the outcome of a curriculum design may be, a school curriculum can be regarded as successful only if it involves the teacher in as many curriculum decisions as possible (Steyn, 2006).

\subsection{Curriculum Policy in South Africa - An Overview}

The National Curriculum Statement Grades R-12 (NCS) stipulates policy on curriculum and assessment in the schooling sector. To improve implementation, the National Curriculum Statement was amended, with the amendments coming into effect in January 2012. A single comprehensive Curriculum and Assessment Policy document was developed for each subject to replace Subject Statements, Learning Programme Guidelines and Subject Assessment Guidelines in Grades R-12. The National Curriculum Statement Grades R-12 (January 2012) represents a policy statement for learning and 
teaching in South African schools and comprises the following:

i. Curriculum and Assessment Policy Statements for each approved school subject;

ii. The policy document, National policy pertaining to the programme and promotion requirements of the National Curriculum Statement Grades R-12; and

iii. The policy document, National Protocol for Assessment Grades R-12 (January 2012).

\subsubsection{Preceding Policy Documents}

The National Curriculum Statement Grades R-12 (January 2012) replaces the two current national curricula statements, namely the:

i. Revised National Curriculum Statement Grades R-9, Government Gazette No. 23406 of 31 May 2002, and

ii. National Curriculum Statement Grades 10-12 Government Gazettes, No. 25545 of 6 October 2003 and No. 27594 of 17 May 2005.

The national curriculum statements contemplated in subparagraphs $b$ (i) and (ii) comprise the following policy documents which will be incrementally repealed by the National Curriculum Statement Grades R-12 (January 2012) during the period 2012-2014:

i. The Learning Area/Subject Statements, Learning Programme Guidelines and Subject Assessment Guidelines for Grades R-9 and Grades 10-12;

ii. The policy document, National Policy on assessment and qualifications for schools in the General Education and Training Band, promulgated in Government Notice No. 124 in Government Gazette No. 29626 of 12 February 2007;

iii. The policy document, the National Senior Certificate: A qualification at Level 4 on the National Qualifications Framework (NQF), promulgated in Government Gazette No.27819 of 20 July 2005;

iv. The policy document, an addendum to the policy document, the National Senior Certificate: A qualification at Level 4 on the National Qualifications Framework (NQF), regarding learners with special needs, published in Government Gazette, No.29466 of 11 December 2006, is incorporated in the policy document, National policy pertaining to the programme and promotion requirements of the National Curriculum Statement Grades R-12; and

v. The policy document, an addendum to the policy document, the National Senior Certificate: A qualification at Level 4 on the National Qualifications Framework (NQF), regarding the National Protocol for Assessment (Grades R-12), promulgated in Government Notice No.1267 in Government Gazette No. 29467 of 11 December 2006.

\subsubsection{General aims of the South African Curriculum}

(a) The National Curriculum Statement Grades R-12 gives expression to the knowledge, skills and values worth learning in South African schools. This curriculum aims to ensure that children acquire and apply knowledge and skills in ways that are meaningful to their own lives. In this regard, the curriculum promotes knowledge in local contexts, while being sensitive to global imperatives.

(b) The National Curriculum Statement Grades R-12 serves the purposes of:

i. equipping learners, irrespective of their socio-economic background, race, gender, physical ability or intellectual ability, with the knowledge, skills and values necessary for self-fulfilment, and meaningful participation in society as citizens of a free country;

ii. providing access to higher education;

iii. facilitating the transition of learners from education institutions to the workplace; and

iv. providing employers with a sufficient profile of a learner's competences.

\subsubsection{Principles of the National Curriculum Statement Grades $R-12$}

The National Curriculum Statement Grades R-12 is based on the following principles:

i. Social transformation: ensuring that the educational imbalances of the past are redressed, and that equal educational opportunities are provided for all sections of the population;

ii. Active and critical learning: encouraging an active and critical approach to learning, rather than rote and uncritical learning of given truths; 
iii. High knowledge and high skills: the minimum standards of knowledge and skills to be achieved at each grade are specified and set high, achievable standards in all subjects;

iv. $\quad$ Progression: content and context of each grade shows progression from simple to complex;

v. Human rights, inclusivity, environmental and social justice: infusing the principles and practices of social and environmental justice and human rights as defined in the Constitution of the Republic of South Africa. The National Curriculum Statement Grades R-12 is sensitive to issues of diversity such as poverty, inequality, race, gender, language, age, disability and other factors;

vi. Valuing indigenous knowledge systems: acknowledging the rich history and heritage of this country as important contributors to nurturing the values contained in the Constitution; and

vii. Credibility, quality and efficiency: providing an education that is comparable in quality, breadth and depth to those of other countries.

\subsubsection{Aims of the National Curriculum Statement Grades R-12}

The National Curriculum Statement Grades R-12 aims to produce learners that are able to:

i. $\quad$ identify and solve problems and make decisions using critical and creative thinking;

ii. $\quad$ work effectively as individuals and with others as members of a team;

iii. organise and manage themselves and their activities responsibly and effectively;

iv. collect, analyse, organise and critically evaluate information;

v. communicate effectively using visual, symbolic and/or language skills in various modes;

vi. use science and technology effectively and critically showing responsibility towards the environment and the health of others; and

vii. demonstrate an understanding of the world as a set of related systems by recognising that problem solving contexts do not exist in isolation.

\section{Curriculum Change}

Curriculum change has been a universal, global tendency (Pretorius \& Lemmer, 1998). Change in the curriculum affects the lives, relationships and working patterns of teachers, and the educational experiences of learners.

It affects parents by altering the education which their children receive and thereby confirming or challenging their own expectations of what school should be like. It affects the community at large, which aware of the school through the outward conduct and attitude of pupils, rightly or wrongly understood.

It affects employers, who derive their view of the curriculum from a rough and ready measurement of how the abilities and aptitudes of the boys and girls they recruit match their requirements.

Curriculum changes because it should not only be the means for students to learn, but it should also provide students with what is needed for life after school. Each learner should be competent with the outside world in as far as knowledge is concerned. Knowledge is perceived to be a process rather than product, which is collectively created, dynamic and changing (Gilbert, 2005).

Curriculum 2005 (2005) was introduced as a policy document in 1997, Revised National Curriculum System in 2002, National Curriculum Statement 2007 and Curriculum and Assessment Statement introduced to be implemented in 2012, which is the one currently in use.

The impact of such change depends on conditions like availability of successfully framed human resource, equipment to implement the curriculum and also the infrastructure. Infrastructure facilitates the production of goods and services and also the distribution of finished products to markets, as well as basic social services such as schools (http://en.m.wiki/lnfrastructure\#/search).

In this case of the school scenario, knowledge and skills for learners are goods which need to be serviced by teachers and learners has to produce what they have learnt and acquired from school to the outside world. So, continuous change in curriculum may affect teaching and learning due to the above mentioned reasons.

Knowledge then depends to what a learner has to learn at that time and what skills are required for the learner to have achieved the outcome. Also what are the societal and also nationwide demands are there at that time hence curriculum needs to be revisited and changed.

One of the difficulties in curriculum change is that it involves the introduction of a new discourse about education. It takes time for people to understand and come to accept new ways of thinking about education (Hoadley \& Jansen 2002). It will probably take even longer for those charged with implementing the new curriculum - the teachers- to move out of 
the 'comfort zone' of habit and tradition.

All attempts at transforming the curriculum must, ultimately, improve teaching and learning. It is vital to engage, communicate with, and support teachers from the outset in attempting to transform the curriculum.

\section{Curriculum Changes in South Africa: Teachers' Perceptions}

It should be noted that the South African education sector has experienced multiple curriculum changes since 1994, as the curriculum needed to be revised to reflect the democratic values and principles contained in the constitution of South Africa (DOE, 2008). The changes in curriculum necessitated a probe into teachers' conceptions and beliefs about the curriculum change and its effects on teaching.

Teachers know the local situation, the local dynamics. Unless teachers are available and willing to participate in curriculum development, there is no future for it. A seminar on Primary Teacher Education held in Sierra Leon, recommended that studies of curriculum development might be introduced into the curriculum programmes of the professional training of teachers (Bishop 1994). The teachers are not against reforms as much as they are offended at the way they are presented to them, not to mention impose on them.

Some teachers are reluctant to see changes come. Many lack skills and knowledge to carry out an innovation. In Britain, the retraining of experienced teachers is one of the most crucial components of curriculum development (Bishop 1994). Fullan (2007) indicates that teachers are the principal agents in curriculum change.

Teachers' beliefs and conceptions shape and strengthen the curriculum development in a country.

The DOE (2009) reiterates that teachers hold certain understandings about the curriculum that are not intended by the policy. It is therefore important to bear in mind the fact that teachers' views and beliefs might not be in line with the educational policy. Sometimes teachers agitate correctly for improvements, but at other times they simply don't do things because tasks are too demanding (Hoadley \& Jansen, 2002). Pudi (2006) contends that there is a fundamental problem emanating from teachers' understanding of the way educational transformation unfolds.

Swannepoel and Booysen (2006) say that in the past, teachers did not associate with the changes that were effected in the curriculum, as they did not believe that these changes would improve their teaching and learners' learning. Vandeyer and Killen (2007) argue that, any effort to change teachers' pedagogical practise needs to acknowledge their conception. Teachers' embedded assumptions about teaching must be controlled in order for any curriculum review to achieve its intended outcomes (Spreen \& Vally, 2010).

In a survey of 1500 non-university teachers at all levels, it was reported that teachers had confidence in methods of decision making, and had faith in textbooks and the didactic methods embedded in them. The majority believed in learning based on investigation rather than memorisation. They worried about pupil motivation and the influence of the mass media (Boyd-Barrett \& O'Malley, 1995).

\section{Conclusion and Recommendations}

Policy developers may have an understanding of the nature of the experiences in education and restructure their curriculum development and planning strategies. There is need for them to revisit their planning by involving teachers from different school categories, that is, rural as well as urban school teachers and also parents from these communities must not be left out at any stage of curriculum development. These will alleviate teachers as they are responsible for implementing the new curriculum.

South Africa Government should actively involve the teachers in formulating or drafting any policy that will affect curriculum since they are the custodians and implementers of the curriculum. Not only that, changes in curriculum should not come overnight; there should a year or two for piloting any new curriculum so as to see the effect and its validity before being released for use in schools. This will enable South African students to be creative, able to communicate effectively, and solve problems and be good independent decision makers.

\section{References}

Bandura, A. (1977). Social learning theory. Englewood Cliffs. NJ: Prentice Hall. Babbie, C. M. (2006). The practise of social research. London: Eve Howard Press.

Becher , T. \& Maclure, S. (1978). The politics of curriculum change. London: Hutchison.

Bishop, G. (1994). Curriculum Development. London: MacMillan Press Ltd.

Cohen, L., \& Manion, K. (2007). Research methods in education, $6^{\text {th }}$ edition. London: Routledge/ Falmer. 
Costa, A. L., \& Liebman, R. M. (1997). Envisioning Process as Content toward a Renaissance Curriculum. California: Corwin Press, Inc. California.

Department of Education. (2009).Final Report: Report of The Task Team for the Review of the implementation of the National Curriculum Statement. Pretoria: Government Printers.

Department of Basic Education, DBE (2012). National protocol for assessment grades R - 12. Pretoria: Government Printers. Retrieved from: http://www.education.gov.za

Dumming, P. A., Dreyer, H. J. \& Steyn, P. D. G. (1991). Education for student teacher. Cape Town: Maskew Miller Longman Ltd.

Eastern Cape Department of Education, (2003). Revised National Curriculum Statement. Pretoria: Government Press.

Fourie, D. L., Grissel, M. \& Verstel, T. L. (1990). Education 1, Advanced College Series. Pietermaritzburg: Via Africa.

Fullan, M. G. (2007).The New Meaning of Educational change. London: Cassel.

Gilbert, J. (2005). Catching the Knowledge Wave? The knowledge Society and the Future of Education. New Zealand: NZCER.

Hewitt, T. W. (2006). Understanding and Shaping Curriculum. What we teach and why. United States of America: Sage Publications, Inc.http://en.m.wiki/Infrastructure\#/search

Jacobs, M., Vakalisa, N. \& Gawe, N. (2006). Teaching-learning Dynamics. Sandown: Heinemann Publishers (Pty) Ltd.

Kyriacou, C. (2001). Effective Teaching in Schools. Spain: Graphy Cems.

MacMillan, J. H. \& Schumacher, S. (2001). Research in education: A conceptual introduction. $5^{\text {th }}$ Edition. New York: Longman.

MacMillan, J.H. \& Schumacher, S. (2006). Research in education evidence based inquiry $6^{\text {th }}$ ed. Boston: Pearson.

Maree, K. (2008). First Steps in Research. Pretoria: Van Schaik Publishers

Mammen, K. J. \& Molepo, J. M. (2008). Faculty of Education hand out. Mthatha: WSU.

Mda, T. \& Mothatha, S. (2000). Critical issues in South African Education after 1994. Knwyn: Juta.

Meyer, L., Lombard, K., Warnich, P., \& Wolhuter, C. (2010). Outcomes - based assessment for South African teachers. Pretoria: Van Schaik Publishers.

Pajares, F. (1996). Self-efficacy beliefs in academic settings. Review of Educational Research, 66, 543-578.

Pudi, T. (2006). From OBE to C2005 to RNCS: Are we still on track? African education review. 3(3):100-112.

Schunk, D., \& Zimmerman, B. (1994). Self-regulation of learning and performance: Issues and educational applications. Hillside..., NJ: Erlbaum.

Spreen, CA. \& Valley, S. (2010). Outcomes Based Education and its contents: Learner centred pedagogy and the education crisis in South Africa. Southern African Review of Education (SARE), 16(1): 39-58.

Steyn, J. C., De Klerk J. \& Du Plessis, W. S. (2006). Education for Democracy. Durban Ville: Wachwas Publishers cc.

Swannepoel, C. \& Boyce, J. (2006). The involvement of teachers in school change: A comparison between the views of school principals in South Africa and nine other countries. South African journal of education. 27(1): 189-198.

Vandeyer, S. \& Killen, R. (2007). Educators' conceptions and practises of classroom assessment in post-apartheid South Africa. South African Journal of Education. 27(1): 101-115.

Valero, P. \& Skovsmose, O. (2002). Proceedings of the $3^{\text {rd }}$ International MES Conference Copenhagen: Centre for Research in Learning Mathematics, pp. 1-10. www.nmmu.ac./za/Robert/fslide4.htm

White, C. J. (2005). Research in practical guide. Pretoria: Ithuthuko investment Publishers. 